\title{
Child Single Worst Criterion as a Predictor of Hemostatic State in Patients with Liver Cirrhosis
}

\author{
Karmel L. Tambunan ${ }^{*}$
}

\begin{abstract}
Abstrak
Pada penderita sirosis hati beratnya gangguan hemostasis erat hubungannya dengan tingkatt sirosis. Pemeriksaan hemostasis lebih kompleks dan menyita waktu yang lama dibandingkan dengan pemeriksaan yang diperlukan untuk menentukan tingkat beratnya sirosis hati. Tingkat berat sirosis hati, dipilih yang paling sederhana, yaitu Child single worst criterion. Dilakukan pemeriksaan hemostasis pada 121 kasus pasien sirosis hati yaitu kadar fibrinogen, Faktor II, Faktor VII, Faktor IX, Faktor X, ATIII, MP, MPT. Pasien dibagi dalam 3 grup yaitu Child A 18 kasus, Child B 48 kasus dan Child C 53 kasus. Sebagai kasus kelola diperiksa 65 orang normal. Ditemukan kadar fibrinogen, Faktor II, Faktor IX, Faktor X, AT III, dan MP pada orang normal berbeda bermakna ( $p<0,05)$ dibandingkan dengan pasien sirosis hati tingkat paling ringan (Child A), kecuali $F$ VII $(p=0,3085)$, MTP $(p=0,3009)$. Pasien sirosis hati antara Child A dan Child B menunjukkan semua hasil hemostasis berbeda bermakna $(p<0,05)$, kecuali fibrinogen $(p=0,1578)$ dan Faktor IX $(p=0,0673)$ sedang pasien sirosis hati antara Child $B$ dan Child C menunjukkan semua hasil hemostasis berbeda bermakna. Dari data tersebut diambil kesimpulan bahwa tingkat sirosis hati berdasarkan Child single worst criterion dapat dipakai untuk menentukan tingkat beratnya gangguan hemostasis. Pemeriksaan penyaring hemostasis antara orang normal dan sirosis hati Child $A$ menunjukkan MP berbeda bermakna $(p<0,0012)$ sedang MPT berbeda tidak bermakna $(p=0,3009)$. Data ini mengingatkan MP merupakan pemeriksaan penyaring yang berguna untuk penderita sirosis hati.
\end{abstract}

\begin{abstract}
s
In liver cirrhosis, the severity of the coagulation disorder is closely related to the severity of the liver dysfunction. A complete hemostatic evaluation involves a multitude of complex measurements which is time consuming and requires a much longer time than the liver function assessment itself. The author has selected the Child criteria for the "worst criteria study" as it was the simplest to use. Hemostatic assessment was performed on 121 cases of liver cirrhosis, i.e., fibrinogen, factors II, VII, IX, X, AT III levels, prothrombin time and partial thromboplastin time. The patients were divided into 3 gorups, i.e., Child A 18 cases, Child B 48 cases, and Child C 53 cases. Sixty five normal volunteers were used as controls.The levels of fibrinogen, factors II, $I X, X$, as well as $A T I I I$ and the prothrombin times among normal persons were significantly different $(p<0.05)$ from Child A, except for factor VII $(p=0.3085)$ and $P T T(p=0.3009)$. There was a significant difference between Child $A$ and Child $B$ liver cirrhosis patients in their hemostasis results ( $p<0.05)$, except for fibrinogen ( $p=0.1578)$ and factor IX $(p=0.0673)$, whereas all hemostatic parameters were significantly different between Child $B$ and Child C patients.The above data shows that the Child single worst criterion as related to the severity of liver cirrhosis can be utilized to determine the severity of the hemostatic abnormality. The hemostatic screening tests performed on normal persons and Child $A$ liver cirrhosis patients revealed significant difference in the prothrombin time $(p<0.0012)$ whereas the PTT was not significantly different $(p=0.3009)$. This data reminds us of the importance of the prothrombin tests in cirrhosis patients.
\end{abstract}

Keywords : liver cirrhosis, Child classification, hemostasis

Bleeding as one of the causes of death in liver cirrhosis has been a known fact. ${ }^{1,2}$ In Indonesia, bleeding in liver cirrhosis has been reported to be in the range of $56-65 \%{ }^{3,4}$ Bleeding as cause of death in Indonesia was reported to be $32-45 \%$ in the span of time between 1978 and 1983 , decreasing to $26.7 \% \%^{5,6,7}$ in the years between 1983 and $1990 .^{8}$ These figures were higher than that reported in the Western literature $(10.5 \%){ }^{1}$

\footnotetext{
* Subdivision of Hematology-Medical Oncology, Department of Internal Medicine, School of Medicine, University of Indonesia/Dr. Cipto Mangunkusumo Hospital, Jakarta, Indonesia
}

The severity of bleeding was very closely related to the hemostatic disorder, which in turn was related to severity of the liver cirrhosis. ${ }^{9}$ The severity of liver cirrhosis can be determined with the liver index, ${ }^{10}$ the Child-Pugh score ${ }^{11}$ and the Child Single Worst Criterion which is parameter of the Child classification selected as the worst and represent the whole. ${ }^{12}$ The Child-Pugh score is time consuming to establish as it needs a scoring system. The Child criteria was introduced by Child in 1964 for the postoperative assessment of liver cirrhosis patients based on clinical and laboratory criteria. ${ }^{13}$ In liver cirrhosis patients with bleeding emergency, quick action is needed but 
hemostatic assessment takes too long. It is faster and easier to determine the severity of liver disease than the hemostasis status.

Based on these problems, a study was started to determine the correlation between hemostasis and liver disease with the Single Worst Criterion as reference. The aim of the study was to determine whether the Child Single Worst Criterion can be used to determine the severity of hemostatic disorder in liver cirrhosis.

\section{METHODS}

Patients included in this study were those previously diagnosed with liver cirrhosis. The diagnosis of liver cirrhosis was based on clinical and laboratory criteria, ultrasonography and was confirmed by the biopsy in three patients. Examination included physical, laboratory liver function and hemostasis assessment. Physical examination included consciousness, nutritional state and ascites. Laboratory tests included liver function, albumin and bilirubin. Hemostasis: PT, PTT, Factors II, VII, IX, X, the AT III levels, fibrinogen. Patients were categorized into Child A, B and C. The control group consisted of healthy teaching staff at the faculty, residents, nurses and laboratory technicians.
Hemostasis measurements utilized the Behring Chromotimer System equipment using the chromogenic substrate method. Statistical analysis was performed using the Student $\mathrm{T}$ test and Pearson coefficient correlation.

\section{RESULTS}

The patients eligible for calculations numbered 121 cases. 119 among them completing all tests. These patients were then subsequently checked physically, undergoing laboratory tests for liver function and hemostasis. The control cases numbered 65 , consisting of normal persons. Based on the Child single worst criterion, the liver cirrhosis cases were divided into 3 groups, i.e., Child A 18 cases, Child B 48 cases, and Child C 53 cases. Sixty five control cases were also checked for hemostasis status.

The results of hemostasis among liver cirrhosis based on the Child single worst criterion and the $p$ values between the normal and liver cirhosis patients can be seen in Table 1 and 2 . The frequency distribution of coagulation factors deficiencies can be seen in Table 3.

Table 1. Mean values and hemostasis among the liver cirrhosis patients based on child criteria and normal group

\begin{tabular}{lcccr}
\hline & $\begin{array}{c}\text { Normal } \\
(\mathrm{n}=65)\end{array}$ & $\begin{array}{c}\text { Child A } \\
(\mathrm{n}=18)\end{array}$ & $\begin{array}{c}\text { Child B } \\
(\mathrm{n}=48)\end{array}$ & $\begin{array}{c}\text { Child C } \\
(\mathrm{n}=53)\end{array}$ \\
\hline Fibrinogen (mg/d) & $350,53 \pm 90,74$ & $279,89 \pm 76,01$ & $236,90 \pm 116,73$ & $172,08 \pm 67,49$ \\
F II (\%) & $107,73 \pm 16,89$ & $82,39 \pm 17,39$ & $66,07 \pm 16,33$ & $45,09 \pm 13,82$ \\
VII (\%) & $108,62 \pm 36,90$ & $98,63 \pm 33,92$ & $69,59 \pm 26,75$ & $51,16 \pm 27,32$ \\
IX (\%) & $97,34 \pm 20,14$ & $74,07 \pm 34,96$ & $56,99 \pm 31,80$ & $42,76 \pm 18,25$ \\
X (\%) & $101,17 \pm 20,06$ & $82,71 \pm 31,02$ & $63,07 \pm 18,67$ & $49,65 \pm 15,47$ \\
AT III (\%) & $115,12 \pm 18,25$ & $88,09 \pm 22,25$ & $69,61 \pm 20,63$ & $44,75 \pm 18,55$ \\
PT (\%) & $89,76 \pm 14,75$ & $78,73 \pm 26,93$ & $55,17 \pm 14,97$ & $40,35 \pm 13,17$ \\
PTT (second) & $119,78 \pm 16,46$ & $124,44 \pm 18,03$ & $149,39 \pm 29,11$ & $181,24 \pm 35,38$ \\
\hline
\end{tabular}

Table 2. $\mathrm{p}$ Value between normal and liver cirrhosis

\begin{tabular}{|c|c|c|c|c|c|c|}
\hline & \multicolumn{6}{|c|}{$p$ Value (independent student's T) } \\
\hline & $\mathrm{N}$ vs $\mathrm{A}$ & $\mathrm{N}$ vs $\mathrm{B}$ & $\mathrm{N}$ vs C & A vs B & B vs C & A vs $C$ \\
\hline Fibrinogen & 0,0036 & $<0,00001$ & $<0,00001$ & 0,1578 & 0,0009 & $<0,00001$ \\
\hline F II & $<0,00001$ & $<0,00001$ & $<0,00001$ & 0,0009 & $<0,00001$ & $<0,00001$ \\
\hline VII & 0,3085 & $<0,00001$ & $<0,00001$ & 0,0007 & 0,0010 & $<0,00001$ \\
\hline IX & 0,0005 & $<0,00001$ & $<0,00001$ & 0,0673 & 0,0068 & $<0,00001$ \\
\hline$X$ & 0,0035 & $<0,00001$ & $<0,00001$ & 0,0030 & 0,0002 & $<0,00001$ \\
\hline AT III & $<0,00001$ & $<0,00001$ & $<0,00001$ & 0,0027 & $<0,00001$ & $<0,00001$ \\
\hline PT (\%) & 0,0254 & $<0,00001$ & $<0,00001$ & 0,00004 & $<0,00001$ & $<0,00001$ \\
\hline PTT & 0,3009 & $<0,00001$ & $<0,00001$ & 0,0014 & $<0,00001$ & $<0,00001$ \\
\hline
\end{tabular}

N: Normal, A: Child A, B: Child B, C: Child C 
Table 3. Frequency distribution of coagulation factors deficiency among liver cirrhosis patients based on child criteria

\begin{tabular}{|c|c|c|c|c|c|}
\hline & & $\begin{array}{c}\text { Child A } \\
(n=18)\end{array}$ & $\begin{array}{r}\text { Child B } \\
(n=48)\end{array}$ & $\begin{array}{l}\text { Child C } \\
(n=53)\end{array}$ & r \\
\hline Faktor II (\%) & $\begin{array}{l}<75 \\
\geq 75\end{array}$ & $\begin{array}{r}3(16,67 \%) \\
15(83,33 \%)\end{array}$ & $\begin{array}{l}31(64,58 \%) \\
17(35,42 \%)\end{array}$ & $\begin{array}{r}52(98,11 \%) \\
1(1,89 \%)\end{array}$ & 0,8232 \\
\hline AT III (\%) & $\begin{array}{l}<80 \\
\geq 80\end{array}$ & $\begin{array}{l}9(50 \%) \\
9(50 \%)\end{array}$ & $\begin{array}{l}35(72,92 \%) \\
13(27,18 \%)\end{array}$ & $\begin{array}{r}50(94,34 \%) \\
3(5,66 \%)\end{array}$ & 0,7888 \\
\hline Faktor X (\%) & $\begin{array}{l}<70 \\
\geq 70\end{array}$ & $\begin{array}{r}6(33,33 \%) \\
12(66,67 \%)\end{array}$ & $\begin{array}{l}35(72,92 \%) \\
13(27,18 \%)\end{array}$ & $\begin{array}{r}46(86,79 \%) \\
7(13,21 \%)\end{array}$ & 0,7362 \\
\hline Faktor IX (\%) & $\begin{array}{l}<70 \\
\geq 70\end{array}$ & $\begin{array}{r}8(44,44 \%) \\
10(55,56 \%)\end{array}$ & $\begin{array}{l}38(79,00 \%) \\
10(21,00 \%)\end{array}$ & $\begin{array}{r}47(88,68 \%) \\
6(11,32 \%)\end{array}$ & 0,7293 \\
\hline $\begin{array}{l}\text { Fibrinogen } \\
\text { (mg/dl) }\end{array}$ & $\begin{array}{l}<200 \\
\geq 200\end{array}$ & $\begin{array}{r}2(11,11 \%) \\
16(88,89 \%)\end{array}$ & $\begin{array}{l}23(48,00 \%) \\
25(52,00 \%)\end{array}$ & $\begin{array}{l}39(73,58 \%) \\
14(26,42 \%)\end{array}$ & 0,6478 \\
\hline Faktor VII (\%) & $\begin{array}{l}<50 \\
\geq 50\end{array}$ & $\begin{array}{l}0 \\
18(100 \%)\end{array}$ & $\begin{array}{l}12(25,00 \%) \\
36(75,00 \%)\end{array}$ & $\begin{array}{r}52(54,72 \%) \\
1(45,28 \%)\end{array}$ & 0,5303 \\
\hline
\end{tabular}

\section{DISCUSSION}

Hemostatic functions maybe impaired in patients in liver cirrhosis as the result of failure of both the biosynthetic and clearence function of the liver. ${ }^{14}$ In Tables 1 and 2 can be seen the coagulation factors in the normal control group and among liver cirrhosis patients assessed with the Child Single Worst Criterion.

Comparing the normal group with the mildest of the Child criteria (Child A), there was significant difference $(p<0.05)$ in all parameters except for factor VII $(\mathrm{p}=0.3085)$.

There was also a striking decrease in the levels of factor II, differing from the vitamin $\mathrm{K}$-deficient patient in which the decrease was in factor VII. ${ }^{15}$ This finding was different from that reported in the literatures, in which decrease in factor VII was reported to be the most significant finding. ${ }^{15}$ Univariate logistic correlation analysis was done on the protein values, albumin, and coagulation factors.

A strongest relationship was found between factor II $(r=0.572)$ and AT III $(r=0.520)$ followed by factor $X$ $(r=0.434)$, factor VII $(r=0.428)$, factor IX $(r=0.341)$ and fibrinogen $(r=0.335)$. Both data revealed a decrease in coagulation factors in liver cirrhosis especially as a result of a decreased synthesis.
The data supports the statements from previous researchers that liver cirrhosis is accompanied by a decrease in coagulation factor synthesis. ${ }^{14}$

Comparisons among the coagulation factors in each group based on the Child single worst criterion between Child A and Child B revealed them to be significantly different. The levels of coagulation factors in Child B patient showed a significant difference from the Child $\mathrm{C}$ group. This data showed that the last factor to be decreased was fibrinogen. This finding confirmed that decreasing fibrinogen levels were mostly seen in advanced liver cirrhosis. 15

From the results of the abovementioned comparisons it can be concluded that the classification of severity of disease in liver cirrhosis based on the Child single worst criterion can be used to determine hemostasis status. From Table 3 the prevalence of F II deficiency correlated significantly with the severity of Child criteria ( $r=0.8232, p<0.05$ ). It also was the case with other factors, i.e., factors VII $(r=0.729, p), X(r=$ $0.7362, p<0.05$ ), fibrinogen $(r=0.6478, p<0.05)$. The data supported the statement that severity of liver cirrhosis based on the Child single worst criterion can determine the prevalence of coagulation factors deficiency and the levels of coagulation factors.

The hemostatic screening tests performed on normal persons and Child A liver cirrhosis patients revealed significant difference in the prothrombin time 
$(p<0.0012)$ whereas the PTT was not significantly different $(p=0.3009)$. This data reminds us of the importance of the prothrombin tests in cirrhosis patients.

\section{CONCLUSIONS}

The Child single worst criterion can be used to determine severity of hemostic disorder in liver cirrhosis. Prothrombin activity is the most sensitive tests to differentiate between a normal person and a cirrhotic patient.

\section{REFERENCES}

1. Schlichting P, Christensen E, Fauerhold L, et.al. Main causes of death in cirrhosis. Scan J Gastroenterol .1983; $18: 881-8$.

2. Ratnoff OD.. Hemostatic defect in Liver and Billiary Tract Disease. In Disorders of Hemostasis. Ed. Ratnoff. OD, Forbes CD. Grune \& Stratton, Inc .1984.451-72.

3. Reksodiputro AH, Djoerban Z, Muthalib A, dkk. Kelainan Hemostasis Pada Sirosis Hepatis. Kumpulan Naskah Ilmiah Simposium Nasional Penyakit Hati Menahun. Ed. Pang. RTL. dkk. 1978. 276-82.

4. Sulaiman A. Virus hepatitis B, sirosis hati dan karsinoma hepatoselular Kumpulan naskah ilmiah dalam rangka tesis. 1990.139-58.

5. Noer MS, Sulaiman A, Akbar N, dkk. Gambaran Klinik Penderita Sirosis Hepatis yang dirawat di Penyakit Dalam
FKUI - RSCM Simposium Nasional Penyakit Hati Menahun. Ed. Pang. RTL. dkk .1978. 237-45.

6. Hernomo K. Terapi Intensif Pada Perdarahan SMBA pada Sirosis Hepatis.Simposium Nasional Penyakit Hati Menahun. Edr. Pang. RTL. dkk. 1978. 302-9.

7. Adi TE, Rahim K, Oebit IC. Masalah sirosis hati di RS Zainoel Abidin, Naskah lengkap. Pertemuan ilmiah ke-II, PPHI. Ed. Lesmana L. Marwoto J. 1983.217-23.

8. Hernomo K. Hematemesis Melena Karena Perdarahan Varises. Gastroenterologi Hepatologi. Ed. Sulaiman dkk. Informedika. Jakarta.1990. 328-338.

9. de Groote J. Introduction. In Haemostatis Failure in Liver Disease. Ed. Fondu P, Thijs O. Martinus Nijhoff Publ 1984. $1-4$.

10. McDermott, WV. The double portocaval in the treatment of cirrhotic ascites. Surg Gyn Obstetrics. 1960; 110:457-69.

11. Terblanche J, Northover JMA, Bornman D et al. A prospective control trial of sclerotherapy in the long term management of patients after esophageal variceal bleeding. Surg Gyn Obstet 1979; 148:323-33.

12. Cello JP, Grendell JH, Crass RA, Trunkey DD, Corb EE, Heilbron DC. Endoscopic Sclerotherapy Versus Portacaval in Patients with Severe Cirrhosis and Variceal Hemorrhage. N Eng J Med. 1984;311:1589-94.

13. Child GC. The Liver and Portal Hypertension. Philadelphia: WB Saunders. 1964.

14. Robert HR, Cederbaum AI. The liver and blood coagulation. Physiology and pathology: Deficiencies of Factors VII, IX and $\mathrm{X}$ result mainly from synthetic incompetence. Gastroenterol 1972; 63:297-.

15. Parano AJ, Racha E. Hemostatic in Advanced Liver Disease. Seminars in Thrombosis and Hemostasis 1993;19:184-90. 